(c) Group of authors, 2021

UDC 616-08:611.1:615.03

DOI - https://doi.org/10.14300/mnnc.2021.16029

ISSN - 2073-8137

\title{
MANAGEMENT OF ADHERENCE-BASED TREATMENT. CONSENSUS DOCUMENT - CLINICAL GUIDELINES. ENGLISH VERSION
}

Nikolaev N. A. ${ }^{*}$, Martynov A. I. ${ }^{2}$, Skirdenko Yu. P. ${ }^{1}$, Anisimov V. N. ${ }^{3}$, Vasilieva I. A. ${ }^{4}$, Vinogradov O. I. ${ }^{5}$, Lazebnik L. B. ${ }^{2}$ Poddubnaya I. V. ${ }^{6}$, Roitman E. V. ${ }^{7,8}$, Ageev F. T. ${ }^{9}$, Andreev K. A. ${ }^{1}$, Babicheva L. G. ${ }^{6}$, Bunova S. S. ${ }^{10}$, Viktorova I. A. ${ }^{1}$, Volchegorskiy I. A. ${ }^{11}$, Galyavich A. S. ${ }^{12}$, Gaus O. V. ${ }^{1}$, Gomberg V. G. ${ }^{13}$, Gorbenko A. V. ${ }^{1}$, Drapkina O. M. ${ }^{14}$, Ershov A. V. ${ }^{15}, 16$, Zyryanov S. K. ${ }^{17}$, Karpov R. S. ${ }^{18},{ }^{19}$, Kobalava Zh. D. ${ }^{17}$, Kolbasnikov S. V. ${ }^{20}$, Kondratyeva K. O. ${ }^{3}$, Konradi A. O. ${ }^{21}$, Livzan M. A. ${ }^{1}$, Malyavin A. G. ${ }^{2}$, Mareev V. Yu. ${ }^{22}$, Medvedeva I. V. ${ }^{23}$, Mikhaylova N. B. ${ }^{24}$, Moiseev S. V. ${ }^{15}$, Morozova O. L. ${ }^{15}$, Napalkov D. A. ${ }^{15}$, Nedoshivin A. O. ${ }^{21}$, Nelidova A. V. ${ }^{1,25}$, Nechaeva G. I. ${ }^{1}$, Nikiforov V. S. ${ }^{26}$, Pisklakov A. V. ${ }^{1}$, Popov S. V. ${ }^{18}$, Ptushkin V. V. ${ }^{27},{ }^{28}$, Rebrov A. P. ${ }^{29}$, Sayfutdinov R. I. ${ }^{30}$, Semiglazova T. Yu. ${ }^{3}$ Sovalkin V. I. ${ }^{1}$, Sovetkina N. V. ${ }^{13}$, Terentiev V. P. ${ }^{31}$, Totchiev G. F. ${ }^{17}$, Tumyan G. S. 6, 32, Fedorin M. M. 1 ', Fofanova T. V. ${ }^{9}$, Shepel R. N. ${ }^{14}$, Yagoda A. V. ${ }^{33}$, Yakushin S. S. ${ }^{34}$ Cross-disciplinary Working Group of the Russian Scientific Medical Society of Internal Medicine, Gastroenterological Scientific Society of Russia, National Association of experts in Thrombosis, Clinical Hemostasiology and Hemoreology, Gerontological Society of the Russian Academy of Sciences, Russian Oncohematologists Society, Russian Society of Phthisiatrists, Society of Evidencebased Neurology

${ }^{1}$ Omsk State Medical University, Russian Federation

${ }^{2}$ A. I. Yevdokimov Moscow State University of Medicine and Dentistry, Russian Federation

${ }^{3}$ N. N. Petrov National Medical Research Center of Oncology, Saint Petersburg, Russian Federation

${ }^{4}$ National Medical Research Center of Tuberculosis and Infectious Diseases, Moscow, Russian Federation

${ }^{5}$ N. I. Pirogov National Medical and Surgical Center, Moscow, Russian Federation

${ }^{6}$ Russian Medical Academy of Continuous Professional Education, Moscow, Russian Federation

7 N. I. Pirogov Russian National Research Medical University (Pirogov Medical University), Moscow, Russian Federation

${ }^{8}$ Research Center of Neurology, Moscow, Russian Federation

${ }^{9}$ National Medical Research Center of Cardiology, Moscow, Russian Federation

${ }^{10}$ Belgorod National Research University, Russian Federation

${ }^{11}$ South-Ural State Medical University, Chelyabinsk, Russian Federation

12 Kazan State Medical University, Russian Federation

${ }^{13}$ Medical-Social Geriatric Center, Saint Petersburg, Russian Federation

${ }^{14}$ National Research Center for Preventive Medicine, Moscow, Russian Federation

${ }^{15} \mathrm{I}$. M. Sechenov First Moscow State Medical University (Sechenov University), Russian Federation

${ }^{16}$ V. A. Negovsky Research Institute of General Reanimatology, Federal Research and Clinical Center of Intensive Care Medicine and Rehabilitology, Moscow, Russian Federation

${ }^{17}$ Peoples' Friendship University of Russian, Moscow

18 Tomsk National Research Medical Center of the Russian Academy of Sciences, Russian Federation

${ }^{19}$ Siberian State Medical University, Tomsk, Russian Federation

${ }^{20}$ Tver State Medical University, Russian Federation

${ }^{21}$ V. A. Almazov National Medical Research Centre, Saint Petersburg, Russian Federation

22 M. V. Lomonosov Moscow State University, Russian Federation

${ }^{23}$ Tyumen State Medical University, Russian Federation

${ }^{24}$ I. P. Pavlov First State Medical University, Saint Petersburg, Russian Federation

${ }^{25}$ City Clinical Cardiology Hospital, Omsk, Russian Federation

${ }^{26}$ I. I. Mechnikov North-Western State Medical University, Saint Petersburg, Russian Federation

27 S. P. Botkin City Clinical Hospital, Moscow, Russian Federation

28 Dmitry Rogachev National Medical Research Center of Pediatric Hematology, Oncology and Immunology, Moscow, Russian Federation

${ }^{29}$ V. I. Razumovsky Saratov State Medical University, Russian Federation

30 Orenburg State Medical University, Russian Federation

${ }^{31}$ Rostov State Medical University, Rostov-on-Done, Russian Federation

32 N. N. Blokhin National Medical Research Center of Oncology, Moscow, Russian Federation

${ }^{33}$ Stavropol State Medical University, Russian Federation

${ }^{34}$ I. P. Pavlov Ryazan State Medical University, Russian Federation

*For requests: med@omgmu.ru, niknik.67@mail.ru,+79136782566. 644043, Krasnyi Put str, 18-32, Omsk, Russian Federation. 


\section{УПРАВАЕНИЕ АЕЧЕНИЕМ НА ОСНОВЕ ПРИВЕРЖЕННОСТИ. КОНСЕНСУСНЫЙ АОКУМЕНТ - КАИНИЧЕСКИЕ РЕКОМЕНААЦИИ. АНГАОЯЗЫЧНАЯ ВЕРСИЯ}

Н. А. Николаев ${ }^{1^{*}}$, А. И. Мартынов ${ }^{2}$, Ю. П. Скирденко ${ }^{1}$, В. Н. Анисимов ${ }^{3}$, И. А. Васильева ${ }^{4}$, О. И. Виноградов $^{5}$, Л. Б. Лазебник ${ }^{2}$, И. В. Поддубная ${ }^{6}$, Е. В. Ройтман ${ }^{7,8}$, Ф. Т. Агеев ${ }^{9}$, К. А. Андреев ${ }^{1}$, Л. Г. Бабичева $^{6}$, С. С. Бунова ${ }^{10}$, И. А. Викторова ${ }^{1}$, И. А. Волчегорский ${ }^{11}$, А. С. Галявич ${ }^{12}$, О. В. Гаус ${ }^{1}$, В. Г. Гомберг ${ }^{13}$, А. В. Горбенко ${ }^{1}$, О. М. Драпкина ${ }^{14}$, А. В. Ершов ${ }^{15},{ }^{16}$, С. К. Зырянов ${ }^{17}$, Р. С. Карпов ${ }^{18,}{ }^{19}$, ж. Д. Кобалава ${ }^{17}$, С. В. Колбасников ${ }^{20}$, К. О. Кондратьева ${ }^{3}$, А. О. Конради ${ }^{21}$, М. А. Ливзан ${ }^{1}$, А. Г. Малявин ${ }^{2}$, В. Ю. Мареев ${ }^{22}$, И. В. Медведева ${ }^{23}$, Н. Б. Михайлова ${ }^{24}$, С. В. Моисеев ${ }^{15}$, О. Л. Морозова ${ }^{15}$, Д. А. Напалков ${ }^{15}$, A. О. Недошивин $^{21}$, А. В. Нелидова ${ }^{1,25}$, Г. И. Нечаева ${ }^{1}$, В. С. Никифоров ${ }^{26}$, А. В. Писклаков ${ }^{1}$, С. В. Попов ${ }^{18}$, В. В. Птушкин ${ }^{27,28}$, А. П. Ребров ${ }^{29}$, Р. И. Сайфутдинов ${ }^{30}$, Т. Ю. Семиглазова ${ }^{3}$, В. И. Совалкин ${ }^{1}$, Н. В. Советкина ${ }^{13}$, В. П. Терентьев $^{31}$, Г. Ф. Тотчиев ${ }^{17}$, Г. С. Тумян ${ }^{6,32}$, М. М. Федорин ${ }^{1}$, Т. В. Фофанова ${ }^{9}$, Р. Н. Шепель ${ }^{14}$, А. В. Ягода ${ }^{33}$, C. С. Якушин ${ }^{34}$ в составе междисциплинарной рабочей группы Российского научного медицинского общества терапевтов, Научного общества гастроэнтерологов России, Национальной ассоциации специалистов по тромбозам, клинической гемостазиологии и гемореологии, Геронтологического общества при РАН, Российского общества онкогематологов, Российского общества фтизиатров, Общества доказательной неврологии

1 Омский государственный медицинский университет, Российская Федерация

${ }^{2}$ Московский государственный медицинский университет имени А. И. Евдокимова, Российская Федерация

${ }^{3}$ Национальный медицинский исследовательский центр онкологии имени Н. Н. Петрова, Санкт-Петербург, Российская Федерация

${ }^{4}$ Национальный медицинский исследовательский центр фтизиопульмонологии и инфекционных заболеваний, Москва, Российская Федерация

${ }^{5}$ Национальный медико-хирургический центр имени Н. И. Пирогова, Москва, Российская Федерация

6 Российская медицинская академия непрерывного медицинского образования, Москва, Российская Федерация

${ }^{7}$ Российский национальный исследовательский медицинский университет имени Н. И. Пирогова (Пироговский медицинский университет), Москва, Российская Федерация

${ }^{8}$ Научный центр неврологии, Москва, Российская Федерация

9 Национальный медицинский исследовательский центр кардиологии, Москва, Российская Федерация

10 Белгородский государственный национальный исследовательский университет, Российская Федерация

11 Южно-Уральский государственный медицинский университет, Челябинск, Российская Федерация

12 Казанский государственный медицинский университет, Российская Федерация

13 Городской гериатрический медико-социальный центр, Санкт-Петербург, Российская Федерация

${ }^{14}$ Национальный медицинский исследовательский центр терапии и профилактической медицины, Москва, Российская Федерация

15 Первый Московский государственный медицинский университет имени И. М. Сеченова (Сеченовский Университет), Российская Федерация

16 Федеральный научно-клинический центр реаниматологии и реабилитологии, Москва, Российская Федерация

17 Российский университет дружбы народов, Москва, Российская Федерация

18 Томский национальный исследовательский медицинский центр Российской академии наук, Российская Федерация

${ }_{19}$ Сибирский государственный медицинский университет, Томск, Российская Федерация

20 Тверской государственный медицинский университет, Российская Федерация

21 Национальный медицинский исследовательский центр имени В. А. Алмазова, Санкт-Петербург, Российская Федерация

22 Московский государственный университет имени М. В. Ломоносова, Российская Федерация

23 Тюменский государственный медицинский университет, Российская Федерация

24 Первый Санкт-Петербургский государственный медицинский университет имени академика И. П. Павлова, Российская Федерация

25 Городской клинический кардиологический диспансер, Омск, Российская Федерация

${ }^{26}$ Северо-Западный государственный медицинский университет имени И. И. Мечникова, Санкт-Петербург, Российская Федерация

27 Городская клиническая больница имени С. П. Боткина, Москва, Российская Федерация

28 Федеральный научно-клинический центр детской гематологии, онкологии и иммунологии имени Дмитрия Рогачева, Москва, Российская Федерация

${ }^{29}$ Саратовский государственный медицинский университет имени В. И. Разумовского, Российская Федерация

30 Оренбургский государственный медицинский университет, Российская Федерация

31 Ростовский государственный медицинский университет, Ростов-на-Дону, Российская Федерация

32 Национальный медицинский исследовательский центр онкологии имени Н. Н. Блохина, Москва, Российская Федерация

${ }_{33}$ Ставропольский государственный медицинский университет, Российская Федерация

34 Рязанский государственный медицинский университет имени академика И. П. Павлова, Российская Федерация

* Автор, ответственный за переписку: med@omgmu.ru, niknik.67@mail.ru, +79136782566644043, Омск, Красный Путь, 18-32. 
Consensus Document «Management of adherence-based treatment» developed based on clinical guidelines of Russian Scientific Medical Society of Internal Medicine approved by the XIV National Congress of physicians (Moscow, 20 November 2019). The document is intended primarily to assess adherence to drug therapy, adherence to lifestyle modification, and adherence to medical support for patients who need long-term or permanent treatment. The document's authors considered the treatment adherence unanimously as the compliance of the patient's behavior with the recommendations received from the Doctor regarding medication, dieting, and other measures of lifestyle modifications. Insufficient adherence to treatment is a global problem. Assessing adherence as a basis for making medical decisions is an essential element of improving the quality of the healthcare system. Predictions of treatment outcomes cannot be considered effective if individualized levels of adherence are not used to justify project planning and evaluation. In medical practice, quantitative assessment of adherence is preferred, suitable for patients with various diseases, and with the possibility of automated data entry and processing. Therefore, sections on medical interventions based on the assessment of treatment adherence should be reflected in national clinical guidelines. These Joint Recommendations are based on these provisions.

Keywords: adherence, quantitative assessment, drug therapy, medical support, lifestyle modification, treatment management

Согласительный документ «Управление лечением на основе приверженности» разработан на основе клинических рекомендаций Российского научного медицинского общества терапевтов, одобренных XIV Национальным конгрессом врачей (Москва, 20 ноября 2019 г.). Документ предназначен в первую очередь для оценки приверженности лекарственной терапии, модификации образа жизни и медицинского сопровождения пациентов, нуждающихся в длительном или постоянном лечении. Приверженность лечению рассматривается авторами документа как соответствие поведения пациента полученным от врача рекомендациям относительно медикаментозного лечения, диеты и других мер по изменению образа жизни. Недостаточная приверженность лечению является глобальной проблемой. Оценка приверженности как основа принятия медицинских решений является важным элементом повышения качества системы здравоохранения. Прогнозы результатов лечения не могут считаться эффективными, если индивидуальные уровни приверженности не используются для обоснования планирования и оценки проекта. В медицинской практике предпочтительна количественная оценка приверженности, подходящая для пациентов с различными заболеваниями и с возможностью автоматизированного ввода и обработки данных. Разделы, посвященные медицинским вмешательствам, основанным на оценке приверженности лечению, должны быть отражены в национальных клинических рекомендациях. На этих ключевых положениях базируются настоящие совместные рекомендации.

Ключевые слова: приверженность, количественная оценка, лекарственная терапия, медицинское сопровождение, модификация образа жизни, управление лечением

For citation: Nikolaev N. A., Martynov A. I., Skirdenko Yu. P., Anisimov V. N., Vasilieva I. A. et al. MANAGEMENT OF ADHERENCE-BASED TREATMENT. CONSENSUS DOCUMENT - CLINICAL GUIDELINES. ENGLISH VERSION. Medical NewS of North Caucasus. 2021;16(2):125-134. DOI - https://doi.org/10.14300/mnnc.2021.16029

Для цитирования: Николаев Н. А., Мартынов А. И., Скирденко Ю. П., Анисимов В. Н., Васильева И. А. и др. УПРАВЛЕНИЕ ЛЕЧЕНИЕМ НА ОСНОВЕ ПРИВЕРЖЕННОСТИ. КОНСЕНСУСНЫЙ ДОКУМЕНТ - КЛИНИЧЕСКИЕ РЕКОМЕНДАЦИИ. АНГЛОЯЗЫЧНАЯ ВЕРСИЯ. Медицинский вестник Северного Кавказа. 2021;16(2):125-134.

DOI - https://doi.org/10.14300/mnnc.2021.16029

\section{Adherence to treatment: concepts and basic po- sitions}

Treatment adherence is defined as the compliance of the patient's behavior with the recommendations received from the Doctor regarding medication, diet, and other lifestyle modifications [1]. The assessment of adherence as a basis for further medical decision-making is an essential element of improving healthcare system efficiency [2-4]. (2A)

There is increasing evidence that treatment adherence is a much more important factor than previously thought. Control of therapy by testing blood and urine samples for drugs demonstrates very low levels of drug adherence. Studies in the general population show that treatment adherence, measured by the regularity of prescription updates, was less than $50 \%$ in half of the patients $[5,6]$. (2A)

Predictions of treatment outcomes cannot be considered effective unless the level of adherence is taken into consideration for project planning and evaluation [7]. Assessing treatment adherence allows avoiding a large number of costly examinations and procedures (including intervention treatment) and unnecessary prescribing of medications [8]. (2A)

Changing treatment adherence is a continuous and flexible process. Any patient population can be segmented according to the level of compliance [9-11]. (1B)
The assessment of the impact of therapeutic strategies on adherence and therapeutic inaction in cross-sectional studies in actual clinical practice is a critical task. The results of such studies regarding the effect of therapy (including combined therapy) on treatment adherence, parameter control, and outcomes are very significant since, in classical randomized controlled trials (RCT) with highly-motivated clinical staff and patients and careful monitoring of treatment, it is extremely difficult to fulfill [12]. (2A)

Assessment of treatment adherence has been done in relatively few studies, compared to the number of studies with different drugs and treatment modes. Therefore, there is little evidence to suggest that a sustained increase in drug adherence can be achieved with modern approaches. This is primarily due to the short duration of most studies, their heterogeneity and flawed design. The efficiency of available technologies improving significantly and sustainably the therapy results should be demonstrated in adequately planned studies based on RCT and cross-sectional design [13-17] . (2B)

Managing treatment based on an identified individual level of adherence or managing treatment adherence can significantly impact public health than improving specific medical treatment $[18,19] .(2 \mathrm{~A})$

Insufficient adherence to treatment is a global problem in modern healthcare systems [20]. Adherence to treating 
patients with chronic diseases is one of the essential factors providing the quality of treatment and directly affecting the prognosis [21-25]. (2A)

Growing evidence proves that low adherence to treatment excluding physician inaction (absence of changing medication in a case when the controlled outcome is not achieved) is a leading cause of inadequate treatment [26-28]. (2A)

Absolute adherence to treatment, i.e., sustained over an extended or unlimited period, when the patient follows accurately all medical guidelines, is registered only in particular RCT and cross-sectional studies and is not typical for actual medical practice [29]. (2A)

General adherence to treatment and its discrete components can be predicted with sufficient accuracy, based on an ever-expanding list of predictors and means of assessing and measuring compliance [30, 31]. (2A)

All known methods of studying adherence to treatment (direct and indirect) have methodological or technological disadvantages [32]. (1A)

Within main methods to assess adherence to treatment (direct question; counting of drugs; measuring the concentration of drugs or their metabolites in the human body's fluids; monitoring visits and interventions, electronic monitoring; use of distance monitoring systems, questionnaires), one of the best is the questionnaire with criteria for time and efficiency. The most commonly and widely used method is to assess adherence to treatment using questionnaires [33]. (2B)

In medical practice, questionnaires are preferable to fulfill quantitative research on adherence to treatment, which are universally applicable in patients with various diseases, and that have the capacity for automatic data entry and processing. (2A)

The value of most standardized questionnaires is limited, whereas other methods, such as the detection of drug levels in blood and urine, are informative but cannot be used commonly [34-36]. The results of questionnaire using are often overestimated relating to treatment adherence. Assessing treatment adherence can be improved by providing cheaper and more reliable methods for identifying drugs used in everyday practice [37]. Traditional short-scale questionnaires to evaluate treatment adherence (e.g., MMAS-4, MMAS-8) have severe limitations due to the high risk of false answers given by patients consciously (leading to significant overestimation of results) [38-41] and, consequently, low test validity. In the Russian Federation, the only questionnaire for quantitative assessment of adherence to treatment according to the scales of drug therapy, medical support, and lifestyle modification, which has a sufficient level of validity and is approved in the prescribed manner by a professional public association, is QAA-25 [42]. (2B)

In assessing adherence to drug therapy, at least $75 \%$ can be considered acceptable and at least $80 \%$ - optimal [43-46]. (2B)

Long-term adherence to any treatment is low, regardless of the disease, and in most cases does not exceed $50 \%$ of the theoretical possibility. The initial adherence to treatment (or individual medical recommendations) has a trend towards declining over time for the majority of patients [47-51]. (1A)

Insufficient adherence to treatment is dangerous with serious health consequences and is an independent factor that worsens the prognosis $[52,53]$. The consequence of insufficient adherence to drug therapy and lifestyle modification is the deterioration of disease progression and prognosis with a simultaneous increase of treatment costs [54-60]. The main disadvantage of lifestyle modification interventions is low adherence to them over time. The global consequences of insufficient adherence to treatment are deterioration of health and increase of overall health costs; the influence of insufficient adherence to treatment increases proportionately to the burden of chronic disease [61, 62]. (2A)

Interventions aimed at increasing adherence to treatment in the short and medium term provide a significant positive return on primary and secondary prevention investment. At the same time, special education programs aimed at increasing treatment adherence reduce their effectiveness over time and are ineffective in the long-term perspective [63]. (2A)

In chronic physical illnesses, the proportion of patients not adhering to treatment is $20-60 \%$ [64, 65]. (2B)

In cardiovascular disease, sufficient adherence to medication compared with insufficient compliance reduces cardiovascular events by $20 \%$ and the risk of death from any disease by 35-40\% [66]. (1A)

Early cessation of drug therapy and inadequate implementation of the guidelines are the most common features of low adherence to treatment. More than $30 \%$ of patients cancel the prescribed therapy by themselves in 6 months and more than $50 \%$ in a year [67]. Within the next 12 months after the coronary event, $30 \%$ of patients cancel the recommended therapy independently, and in the case of arterial hypertension, more than $60 \%$ of patients. Half of them indicate fears of «addiction» and direct «harm» from the therapy as the main reasons [68]. Low adherence to prescribed treatment is a frequent cause of pseudo-resistance, which is detected in $50 \%$ of patients when tested with laboratory monitoring of drug intake [69-71]. (2A)

Predictors of sufficient adherence to treatment are higher education, disability status $[72,73]$, older age [74, 75], and drug use frequency. A single drug intake (including in the form of a fixed combination) is accompanied by a significantly higher adherence to treatment than a double or multiple drug intake [76]. Maximum adherence to drug therapy in patients with chronic physical illnesses is registered in single drug intake $[77,78]$. (1A)

Predictors of insufficient adherence to treatment are a complicated or inconvenient medication schedule, increased length of illness, limited (insufficient) financial resources, lack of confidence to the physician, failure to assess the severity of the illness, lack of trust in treatment success [79-81], fear of undesirable effects of treatment, low levels of education, alcohol abuse $[82,83]$, and sense of well-being [84-86]. Chronic physical illnesses without advanced symptoms are predictors of insufficient adherence to drug therapy. (2A)

In older patients in the Russian population, the leading cause of low adherence to drug therapy is the progression of undesirable effects and fear of similar ones. $(1 \mathrm{~A})$

There is an inverse relationship between the level of adherence and the difficulty of the prescribed treatment schedule. Treatment adherence is significantly affected by the amount of pills prescribed to a patient according to the therapy. Current studies show that the number of patients with low drug adherence was less than $10 \%$ of those who take one pill; the percentage of patients increased to $20 \%$ in case of accepting two pills, to $40 \%$ with three tablets, and got highly prominent, up to complete refusal if a patient was prescribed five or more pills. (2A)

Increasing treatment adherence is facilitated by adapting medication intake to the patient's habits [87], providing available self-monitoring algorithms [88], using special packaging for dosing drugs, conducting 
motivational conversations, providing the transmission of telemetric information from the patient's home, also improving the integration of health care workers with the involvement of pharmacists and nurses, with the best result being a combination of these methods [89, 90]. During treatment, it is extremely important to apply sufficient drug regimens, minimize undesirable effects, and use one dose of medication per day, preferably in fixed combinations $[91,92] .(2 \mathrm{~A})$

Despite the evidence to the contrary, there is still a tendency to focus on finding treatment adherence issues related only to patients, with relative disregard for factors, depended on the service provider and healthcare system [93-95]. The lack of correspondence between the patient's willingness to be treated and the medical practitioner's willingness to treat leads to the fact that treatment is often prescribed to patients who are not ready to follow the proposed volume of medical recommendations [96, 97]. The strategic goal of the quality system in relation to treatment adherence should be the constant readiness of medical practitioners to assess the patient's treatment adherence and provide recommendations based on previously mentioned factors [98, 99]. (2B)

Quantitative assessment criteria for adherence to treatment

Treatment adherence rate of over $75 \%$ means «high». Evaluation of intervention effectiveness: medical recommendations will be implemented or are likely to be implemented. (2B)

Treatment adherence rate with 50-75 \% means «medium». Evaluation of intervention effectiveness: medical recommendations are more likely to be implemented than not. (2B)

Treatment adherence rate with less than $50 \%$ means «low». Evaluation of intervention effectiveness: medical recommendations are not likely to be implemented or will not be implemented. (2B)

Comments: The criteria are intended for quantitative assessment questionnaires of treatment adherence which include the possibility of simultaneous determination of compliance by the scales of drug therapy, medical support, lifestyle modification, and general adherence to treatment. For diseases and conditions requiring longterm (permanent) drug therapy and/or medical support, only a quantitatively measured adherence rate exceeding $75 \%$ of the maximum possible adherence should be interpreted as acceptable (sufficient). Other measured indicator values on any scale should be considered insufficient, as they indicate a high risk of patients' relevant medical recommendations failure.

The effectiveness prediction of medical interventions depending on the level of treatment adherence. To predict the effectiveness of medical interventions, the adherence values obtained on the appropriate scale in a particular patient are correlated with the range of values of the appropriate adherence level, defining adherence as high, medium, or low. The identified adherence level indicates the most likely prognosis for intervention effectiveness. The latter does not exclude specific cases, personal characteristics of a particular respondent, or unrecorded influences that may affect the actual efficacy of the intervention. (2A)

Expected effectiveness of specific interventions depending on the level of adherence to drug therapy. Taking one medication (fixed combination of drugs) once a day: the intervention will be carried out completely, or the intervention is more likely to be carried out completely than partially or omitted with high and medium levels of adherence; the intervention is more likely to be carried out partially than wholly or the intervention is more likely to be carried out partially than omitted with a low level of adherence. (2B)

Taking one medication (fixed combination of drugs) 2 times a day: the intervention will be carried out completely, or the intervention is more likely to be carried out entirely than partly or omitted with a high level of adherence; the intervention is more likely to be carried out partially than completely or the intervention is more likely to be carried out partially than omitted with a medium level of adherence; the intervention is more likely not to be carried out partially or wholly, or it will be omitted with a low level of compliance. (2B)

Taking a medication (fixed combination of drugs) 3 times a day or more frequently: the intervention will be carried out completely, or the intervention is more likely to be carried out completely than partly or omitted with a high level of adherence; the intervention is more likely not to be carried out partially or completely, or it will be missed with medium or low levels of adherence. (2B)

Taking two medications (fixed combinations of drugs) separately once a day: the intervention will be carried out entirely, or the intervention is more likely to be carried out completely than partially or omitted with a high level of adherence; the intervention is more likely to be carried out partially than wholly, or the intervention is more likely to be carried out partially than omitted with a medium level of adherence; the intervention is more likely not to be carried out partially or wholly, or it will be omitted with a low level of adherence. (2B)

Taking two medications (fixed combinations of drugs) separately two times a day: the intervention will be carried out completely, or the intervention is more likely to be carried out completely than partially or omitted with a high level of adherence; the intervention is more likely to be carried out partially than completely or the intervention is more likely to be carried out partially than omitted with a medium level of adherence; the intervention is more likely not to be carried out partially or wholly, or it will be omitted with a low level of adherence. (2B)

Taking two medications (fixed combinations of drugs) separately three times a day, or more frequently: the intervention will be carried out completely, or the intervention is more likely to be carried out completely than partially or omitted with a high level of adherence; the intervention is more likely not to be carried out partially or wholly, or it will be omitted with medium or low levels of adherence. (2B)

Taking three or more medications (fixed combinations of drugs) separately once a day: the intervention will be carried out completely, or the intervention is more likely to be carried out completely than partially or omitted with a high level of adherence; the intervention is more likely not to be carried out partially or wholly, or it will be omitted with medium or low levels of adherence. (2B)

Taking three or more medications (fixed combinations of drugs) separately two times a day: the intervention will be carried out thoroughly, or the intervention is more likely to be carried out completely than partially or omitted with a high level of adherence; the intervention is more likely not to be carried out partially or wholly, or it will be omitted with medium or low levels of adherence. (2B)

Taking three or more medications (fixed combinations of drugs) separately three times a day, or more frequently: the intervention is more likely to be carried out partially than completely, or the intervention is more likely to be carried out partially than omitted with a high level of adherence; the intervention is more likely not to be carried out partially or completely, or it will be omitted with medium or low levels of adherence. (2B) 
Expected effectiveness of specific interventions depending on the level of adherence to medical support. A self-referral to the Doctor, without established routine visits; regular self-monitoring is not required: the intervention will be carried out completely, or the intervention is more likely to be carried out entirely than partially or omitted with high, medium, and low adherence levels. (2B)

A self-referral to the Doctor, with established routine visits more often than once every three months, but less frequently than once a month; regular self-monitoring is not required: the intervention will be carried out completely, or the intervention is more likely to be carried out entirely than partially or omitted with high and medium adherence levels; the intervention is more likely not to be carried out partially or wholly, or it will be omitted with a low level of adherence. (2B)

A self-referral to the Doctor, with established routine visits more than once a month; regular self-monitoring is not required: the intervention will be carried out completely, or the intervention is more likely to be carried out completely than partially or omitted with high and medium adherence levels; the intervention is more likely not to be carried out partially or wholly, or it will be omitted with a low level of adherence. (2B)

A self-referral to the Doctor, without established routine visits; regular self-monitoring is recommended: the intervention will be carried out completely or the intervention is more likely to be carried out entirely than partially or omitted with a high level of adherence; the intervention is more likely to be carried out partially than completely or the intervention is more likely to be carried out partially than omitted with a medium level of adherence; the intervention is more likely not to be carried out partially or wholly, or it will be omitted with a low level of adherence. (2B)

A self-referral to the Doctor, with established routine visits more often than once every three months, but less often than once a month; regular self-monitoring is recommended: the intervention will be carried out completely, or the intervention is more likely to be carried out completely than partially or omitted with a high level of adherence; the intervention is more likely not to be carried out partially or completely, or it will be omitted with medium or low levels of adherence. (2B)

A self-referral to the Doctor, with established routine visits more often than once a month; regular selfmonitoring is recommended: the intervention will be carried out completely, or the intervention is more likely to be carried out completely than partially or omitted with a high level of adherence; the intervention is more likely not to be carried out partially or wholly, or it will be omitted with medium or low levels of adherence. (2B)

Expected effectiveness of specific interventions depending on the level of adherence to lifestyle modification.

Correction of regular diet or exercise is necessary; no restriction or abandonment of bad habits is required: the intervention will be carried out completely or the intervention is more likely to be carried out entirely than partially or omitted with high and medium adherence levels; the intervention is more likely not to be carried out partially or wholly, or it will be omitted with a low level of adherence. (2B)

Correction of regular diet and exercise is necessary; no restriction or abandonment of bad habits is required: the intervention will be carried out completely or the intervention is more likely to be carried out entirely than partially or omitted with a high level of adherence; the intervention is more likely to be carried out partially than wholly, or the intervention is more likely to be carried out partially than omitted with a medium level of adherence; the intervention is more likely not to be carried out partially or completely, or it will be omitted with a low level of adherence. (2B)

Correction of regular diet or exercise is necessary; restriction of bad habits is necessary: the intervention will be carried out thoroughly, or the intervention is more likely to be carried out completely than partially or omitted with a high level of adherence; the intervention is more likely not to be carried out partially or entirely, or it will be omitted with medium or low levels of adherence. (2B)

Correction of regular diet and exercise is necessary; restriction of bad habits is essential: the intervention will be carried out completely, or the intervention is more likely to be carried out entirely than partially or omitted with a high level of adherence; the intervention is more likely not to be carried out partially or wholly, or it will be omitted with medium or low levels of adherence. (2B)

Correction of regular diet or exercise is necessary; abandonment of bad habits is essential: the intervention will be carried out thoroughly, or the intervention is more likely to be carried out completely than partially or omitted with a high level of adherence; the intervention is more likely not to be carried out partially or wholly, or it will be omitted with medium or low levels of adherence. (2B)

Correction of regular diet and exercise is necessary; abandonment of bad habits is necessary: the intervention is more likely to be carried out partially than completely, or the intervention is more likely to be carried out partially than omitted with a high level of adherence; the intervention is more likely not to be carried out partially or completely, or it will be omitted with medium or low levels of adherence. (2B)

Treatment management: choice of treatment strategy based on the prognosis of the effectiveness of the medical intervention.

Treatment management, taking into account the identified levels of adherence in a particular patient, aims to achieve the best possible result of medical interventions.

Choosing a treatment strategy based on the level of adherence to drug therapy

High level of adherence to drug therapy: regular intake of medications up to three times a day inclusive does not reduce the patient's readiness for treatment significantly; medications can be prescribed as fixed or unfixed combinations or both; the number of medications does not affect the patient's readiness for treatment significantly. (2B)

Medium level of medication adherence: the regular taking of medications more than twice a day reduces the readiness of the patient to take them significantly; medications can be prescribed in the form of fixed or unfixed combinations; simultaneous medication intake of three or more medications reduces the readiness of the patient for treatment significantly. (2B)

Low level of medication adherence: ability to follow the regular intake of medication once or more times a day is doubtful; recommendation to take medication regularly, with a frequency of two or more times a day, is ineffective; medication should be prescribed as a single medication or a fixed combination of drugs; simultaneous medication intake of several medications reduces the readiness of the patient to take them significantly; there is an additional risk of appearance of undesirable effects when taking medications requiring long-term titration of doses and (or) having a «rebound syndrome» («withdrawal syndrome»). (2C)

The choice of treatment strategy based on the level of adherence to medical support

High level of adherence to medical support: recommendations for self-monitoring of health condition or particular parameters are adequate; the medical support program should be based on the optimal frequency of 
planned (including preventive) visits, laboratory and instrumental tests. (2B)

Medium level of adherence to medical support: recommendations for self-monitoring of health condition or particular parameters are moderately or poorly effective; the medical support program should be based on the minimum required frequency of planned office visits, with a limited number of tests to be made. (2C)

Low level of adherence to medical support: recommendations for self-monitoring of health condition or particular parameters are poorly effective or ineffective; medications should be prescribed as a single medication or a fixed combination of them; simultaneous medication intake of several medications reduces the readiness of the patient to take them significantly; the medical support program should be based on self-referrals related to changes in symptoms of the disease; preventive visits and routine check-ups are more likely not to be performed than they will be, or will be omitted. (2C)

Choosing a treatment strategy based on the level of adherence to lifestyle modification

High level of adherence to lifestyle modification: recommendations for limiting or avoiding harmful habits (including smoking, alcohol consumption, excessive consumption of food, etc.) can be extensive and detailed; recommendations for correcting a regular diet (including changing the frequency and structure of diet, refusing or reducing the consumption of certain foods, etc.) and exercise regimens (types, frequency, diversity) can cover all aspects of the patient's health. (2C)

Medium level of adherence to lifestyle modification: recommendations for limiting bad habits should be specific and brief; recommendations for abandonment of such habits will be omitted rather than carried out; recommendations for correction of a regular diet, as well as types, frequency, and multiplicity of physical activity, should be presented in the form of specific brief information; these recommendations should primarily refer to the disease which is the most significant in respect of the development of dangerous complications, unfavorable disease progression, and outcomes. (2C)

Low level of adherence to lifestyle modification: recommendations for limiting bad habits should be presented in the form of a limited list of decisions and actions which are the most significant for reducing life-threatening risk; total or partial abandonment of bad habits is unlikely or impossible; recommendations for correcting diet and exercise should be specific and highly brief; general recommendations for correcting diet and exercise are ineffective. (2C)

Disclosures: The authors declare no conflict of interest.

\section{References}

1. Geest S., Sabate E. Adherence to long-term therapies: evidence for action. Eur. J. Cardiovasc. Nurs. 2003;2(4):323. https://doi.org/10.1016/S1474-5151(03)00091-4

2. Alekseev V. N., Malevannaya O. A., El Haj N. S. The reasons of low adherence in primary open-angle glaucoma patients treatment. Ophthalmological journal. 2010;3(4):37-39. [cited 05.01.2020]. Available at: https:// elibrary.ru/download/elibrary_15555091_58697945.pdf.

3. Moisseyev S. V. How to improve compliance to dual antithrombotic treatment after acute coronary syndrome? Clin. Pharmacol. Ther. 2011;20(4):34-40. [cited 05.01.2020]. Available at: https://elibrary.ru/download/ elibrary 22622404 71748330.pdf.

4. Nikolaev N. A., Martynov A. I., Bojcov S. A., Drapkina O. M., Sychev D. A. [et al.] The first Russian consensus on quantitative assessment of treatment outcome. Medical News of North Caucasus. 2019;2(14):283-301. https://doi.org/10.14300/mnnc.2019.14072

5. Corrao G Parodi A Nicotra F Zambon A, Merlino L. [et al.] Better compliance to antihypertensive medications reduces cardiovascular risk. J. Hypertens. 2011;29:610618. https://doi.org/10.1097/HJH.0b013e328342ca97

6. Tiffe T., Wagner M., Rucker V., Morbach C., Gelbrich G. [et al.] Control of cardiovascular risk factors and its determinants in the general population-findings from the STAAB cohort study. BMC Cardiovasc Disord. 2017;17:276. https://doi.org/10.1186/s12872-017-0708-x

7. World Health Organization. Adherence to long-term therapies: evidence for action. WHO Library Cataloguingin-Publication Data, Geneva, WHO 2003;211. [cited 05.01.2020]. Available at: https://apps.who.int/iris/ bitstream/handle/10665/42682/9241545992.pdf

8. Berra E., Azizi M., Capron A., Hoieggen A., Rabbia F. [et al.] Evaluation of adherence should become an integral part of assessment of patients with apparently treatmentresistant hypertension. Hypertension. 2016;68:297-306. https://doi.org/10.1161/HYPERTENSIONAHA.116.07464

9. Nlkolaev N. Patient-oriented antihypertensive therapy: clinical guidelines for the practitioner. The Doctor. 2016;4:82-85. [cited 05.01.2020]. Available at: https:// elibrary.ru/item.asp?id=25934065.

10. Skirdenko Y. P. Nikolaev N. A. Contribution of anticoagulant therapy adherence to the risk of complications of atrial fibrillation. Russian Journal of Cardiology. 2019;(2):64-69.

https://doi.org/10.15829/1560-4071-2019-2-64-69

11. Skirdenko Ju. P., Nikolaev N. A. Quantitative assessment of adherence to treatment in patients with atrial fibrillation in real clinical practice. Therapeutic Archive. 2018;1:17-21. https://doi.org/10.17116/terarkh201890117-21

12. Mancia G., Rea F., Cuspidi C., Grassi G., Corrao G. Blood pressure control in hypertension. Pros and cons of available treatment strategies. J. Hypertens. 2017;35:225233. https://doi.org/10.1097/HJH.0000000000001181

13. Nikolaev N. A. Dokazatel'naya gipertenziologiya: kolichestvennaya ocenka rezul'tata antigipertenzivnoj terapii. M.: Izdatel'skij dom «Akademiya estestvoznaniya». 2008:92. Available at: https://elibrary.ru/item.asp?id=19544653

14. Nikolaev N. A. Dokazatel'naya gipertenziologiya: pacientoorientirovannaya antigipertenzivnaya terapiya. M.: Izdatel'skij dom Akademii estestvoznaniya. 2015:178. Available at: https://elibrary.ru/item.asp?id=25268177.

15. $2018 \mathrm{ESC} / \mathrm{ESH}$ Guidelines for the management of arterial hypertension. European Heart Journal. 2018;39:30213104. https://doi.org/10.1093/eurheartj/ehy339

16. Souza A. C., Borges J. W., Moreira T. M. Quality of life and treatment adherence in hypertensive patients: systematic review with meta-analysis. Revista de Saúde Pública. 2016;50:71.

https://doi.org/10.1590/s1518-8787.2016050006415

17. Marin M., Barochiner J., Rodriguez P., Renna N., Castellaro C. [et al.] Blood pressure control and cardiovascular risk profile in hypertensive patients under spe-cialist care in Argentina: results from the CHARTER study. J. Clin. Hypertens. 2019;21(10):1456-1462.

https://doi.org/10.1111/jch.13684

18. Nikolayev N. A., Skirdenko Yu. P. Russian generic questionnaire for evaluation of compliance to drug therapy. Clin. Pharmacol. Ther 2018;27(1):74-78. [cited 05.01.2020]. Available at: https://clinpharmjournal.ru/files/articles/rossijskij-universalnyj-oprosnikkolichestvennoj-otsenki-priverzhennosti-k-lecheniyukop-25.pdf

19. Skirdenko Yu.P., Nikolaev N. A. Contribution of anticoagulant therapy adherence to the risk of complications of atrial fibrillation. Russian Journal of Cardiology. 2019;24(2):6469. https://doi.org/10.15829/1560-4071-2019-2-64-69

20. Nikolaev N. A., Skirdenko Yu. P., Livzan M. A., Zamakhina O. V. Patient-centered technologies for risk assessment and prognosis of therapy efficacy in cardiology patients: a monograph. Omsk State Medical University. M.: Publishing House of the Academy of Natural Sciences. 2019:232. https://doi.org/10.17513/np.377

21. Ickovics J. R., Meisler A. W. Adherence in AIDS clinical trials: a framework for clinical research and clinical care. J. Clin. Epidemiol. 1997;50(4):385-91.

https://doi.org/10.1016/S0895-4356(97)00041-3 
22. Kastrissios H., Suarez J. R., Hammer S., Katzenstein D., Blaschke T. F. The extent of non-adherence in a large AIDS clinical trial using plasma dideoxynucleoside concentrations as a marker. AIDS. 1998;12(17):2305-2311. https://doi.org/10.1097/00002030-199817000-00012

23. Rotar O. P., Tolkunova K. M., Solntsev V. N., Erina A. M., Boyarinova M. A. [et al.] May Measurement Month 2019: adherence to treatment and hypertension control in Russia. Russian Journal of Cardiology. 2020; 25(3):3745. https://doi.org/10.15829/1560-4071-2020-3-3745

24. Konradi A. O. Znachenie priverzhennosti $k$ terapii $v$ lechenii kardiologicheskih zabolevanij. Spravochnik poliklinicheskogo vracha. 2007;6:8-11.

25. Lomakin N. V., Buryachkovskaya L. I., Senichkina A. A., Sumarokov A. B., Docenko U. V. [et al.] Use of combination pills with acetylsalicylic acid and clopidogrel in coronary artery disease. Efficacy and assessment of adherence to treatment: Kobra Study. Consilium Medicum. 2021;23(1):61-69. https://doi.org/10.26442/20751753.2021.1.200780

26. Corrao G., Zambon A., Parodi A., Poluzzi E., Baldi I. [et al.] Discontinuation of and changes in drug therapy for hypertension amongnewly-treated patients: a populationbased study in Italy. J. Hypertens. 2008;26:819-824. https://doi.org/10.1097/HJH.0b013e3282f4edd7

27. Gale N. K., Greenfield S., Gill P., Gutridge K., Marshall T. Patient and general practitioner attitudes to taking medication to prevent cardiovascular disease after receiving detailed information on risks and benefits of treatment: a qualitative study. BMC Fam. Pract. 2011;12:59 [cited 05.01.2020]. Available at: https://bmcfampract. biomedcentral.com/articles/10.1186/1471-2296-12-59

28. Krousel-Wood M., Joyce C., Holt E., Muntner P., Webber L. S. [et al.] Predictors of decline in medication adherence: results from the cohort study of medication adherence among older adults. Hypertension. 2011;58:804-810. https://doi.org/10.1161/HYPERTENSIONAHA.111.176859

29. Andreev K. A., Plinder M. A., Sidorov G. G., Skirdenko Yu. P., Nikolaev N. A. Osnovnye trendy priverzhennosti k lecheniyu u kardiologicheskih bol'nyh. Sovremennye problemy nauki i obrazovaniya. 2018;3:36-36. [cited 05.01.2020]. Available at: https://rae.ru/pdf/bookspno volume_3.pdf.

30. Skirdenko Ju. P., Zherebilov V. V., Nikolaev N. A. Predictors of adherence to treatment in patients with atrial fibrillation. International Journal of Applied and Fundamental Research. 2016;5. [cited 05.01.2020]. Available at: www.science-sd.com/467-25081

31. Ionov M. V., Zvartau N. E., Dubinina E. A., KhromovBorisov N. N., Tregubenko I. A. [et al.] Hypertension specific patient-reported outcome measure. Part III: validation, responsiveness and reliability assessment. Russian Journal of Cardiology. 2020;25(3):3438. https://doi.org/10.15829/1560-4071-2019-3438

32. Anghel L. A., Farcas A. M., Oprean R. N. An overview of the common methods used to measure treatment adherence. Med. Pharm. Rep. 2019;92(2):117-122. https://doi.org/10.15386/mpr-1201

33. Lukina Yu. V., Kutishenko N. P., Martsevich S. Yu., Drapkina O. M. Questionnaires and scores for assessing medication adherence - advantages and disadvantages of the diagnostic method in research and actual clinical practice. Cardiovascular Therapy and Prevention. 2020;19(3):2562

https://doi.org/10.15829/1728-8800-2020-2562

34. Bakris G. L., Lindholm L. H., Black H. R., Krum H., Linas S. [et al.] Divergent results using clinic and ambulatory blood pressures: report of a darusentan-resistant hypertension trial. Hypertension. 2010;56:824-830.

https://doi.org/10.1161/HYPERTENSIONAHA.110.156976

35. Laurent S., Schlaich M., Esler M. New drugs, procedures, and devices for hypertension. Lancet. 2012;380:591-600. https://doi.org/10.1016/S0140-6736(12)60825-3

36. Vrijens B., Vincze G., Kristanto P., Urquhart J., Burnier M. Adherence to prescribed antihypertensive drug treatments: longitudinal study of electronically compiled dosing histories. BMJ. 2008;336:1114-1117

https://doi.org/10.1136/bmj.39553.670231.25

37. Burnier M. Managing' resistance': is adherence a target for treatment? Curr. Opin. Nephrol. Hypertens. 2014;23:439443. https://doi.org/10.1097/MNH.0000000000000045

38. Zherebilov V. V., Skirdenko Yu. P., Nikolaev N. A Gendernye osobennosti priverzhennosti k lecheniyu u bol'nyh stabil'noj stenokardiej. International journal of experimental education. 2016;4(3):509-510. [cited 05.01.2020]. Available at: https://www.expeducation.ru/ pdf/2016/4-3/9868.pdf.

39. Zhilenko O. M., Kukengemer V. S., Nejfeld M. S., Skirdenko Yu. P. Priverzhennost' k lecheniyu u bol'nyh hronicheskoj serdechnoj nedostatochnost'yu. Nauchnoe obozrenie. Medicinskie nauki. 2017;5:37-40. [cited 07.06.2019]. Available at: https://science-medicine.ru/ru/ article/view?id=1033.

40. Lukina Yu. V., Martsevich S. Yu., Kutishenko N. P. The Moriscos-Green scale: the pros and cons of universal test, correction of mistakes. Rational Pharmacotherapy in Cardiology. 2016;12(1):63-65.

https://doi.org/10.20996/1819-6446-2016-12-1-63-65

41. Nikolaev N. A., Martynov A. I., Skirdenko Yu. P., Anisimov V. N., Vasileva I. A. [et al.] Treatment management based on adherence: patient recommendation algorithms. Cross-disciplinary guidelines. Medical News of North Caucasus. 2020:15(4):461-468.

https://doi.org/10.14300/mnnc.2020.15109

42. Nikolayev N. A., Skirdenko Y. P., Zherebilov V. V. Quantitative assessment of adherence to treatment in clinical medicine: protocol, procedure, interpretation. Kachestvennaya klinicheskaya praktika. 2016;(1):50-59. [cited 05.01.2020]. Available at: https://elibrary.ru/item. asp? id=26375081.

43. Efremova E. V., Menzorov M. V., Sabitov I. A. Treatment compliance in patients with chronic heart failure and comorbidities. Klin. med. 2015;93(9):20-24. [cited 05.01.2020]. Available at: https://cyberleninka.ru/article/n/ priverzhennost-lecheniyu-bolnyh-s-hronicheskoyserdechnoy-nedostatochnostyu-v-usloviyah-komorbidnosti

44. Ho P. M., Bryson C. L., Rumsfeld J. S. Medication adherence: its importance in cardiovascular outcomes. Circulation. 2009;119(23):3028-35. https://doi.org/10.1161/CIRCULATIONAHA.108.768986

45. Hwang S. L., Liao W. C., Huang T. Y. Predictors of quality of life in patients with heart failure. Jpn. J. Nurs Sci. 2014;11(4):290-98.

46. Levine D. A., Morgenstern L. B., Langa K. M., Piette J. D., Mary A. M. [et al.] Recent trends in cost-related medication nonadherence among stroke survivors in the United States. Ann. Neurol. 2013;73(2):180-8. https://doi.org/10.1002/ana.23823

47. Fofanova T. V., Ageev F. T., Smirnova M. D., Svirida O. N., Kuzmina A. E. [et al.] National questionnaire of treatment compliance: testing and application in outpatient practice. System Hypertension. 2014;02:13-16. Available at: https://con-med.ru/magazines/hypertension/ hypertension-02-2014/otechestvennyy oprosnik priverzhennosti_terapii_aprobatsiya_i_primenenie_v_ ambulatornoy_präktike.

48. Arabidze G. G., Belousov Yu. B., Karpov Yu. A. Arterial'naya gipertoniya. Spravochnoe rukovodstvo po diagnostike i lecheniyu. M.: Remedium; 1999:225

49. Zhuravskaya N. Yu. Izuchenie priverzhennostilekarstvennoj terapii bol'nyh serdechno-sosudistymi zabolevaniyami, perenesshih mozgovoj insul't, dissertaciya na soiskanie uchenoj stepeni kand. med. nauk. Gosudarstvennyj nauchno-Issledovatel'skij centr profilakticheskoj mediciny. M.; 2015.

50. Aliotta S. L., Vlasnik Jon J., DeLor Bonnie. Enhancing Adherence to Long-Term Medical Therapy: A New Approach to Assessing and Treating Patients. Advances in Therapy. 2004;21(4):214-231. https://doi.org/10.1007/BF02850154

51. Chowdhury R., Khan H., Heydon E., Shroufi A. [et al.] Adherence to cardiovascular therapy: a meta-analysis of prevalence and clinical consequences. Eur. Heart J. 2013;34(38):2940-2948. https://doi.org/10.1093/eurheartj/eht295

52. Driving Therapy Adherence for Improved Health Outcomes. A Manifesto for the European Elections 2019. [cited 05.01.2020]. Available at: http://www.seniorinternationalhealthassociation.org/wp-content/uploads/2015/05/ SIHA_Manifesto_Booklet_Online-version_without-sign_ spread.pdf

53. World Health Organization. Secondary prevention of non-communicable disease in low and middle-income countries through community-based and health service interventions. 2002. [cited 05.01.2020]. Available at: www.who. int/chp/knowledge/publications/adherence_full_report.pdf 
54. McDonnell P. J., Jacobs M. R. Hospital admissions resulting from preventable adverse drug reactions. Ann. Pharmacother. 2002;36(9):1331-6. https://doi.org/10.1345/aph.1A333

55. Misdrahi D., Llorca P. M., Lançon C., Bayle F. J. Compliance in schizophrenia: predictive factors, therapeutical considerations and research implications. Encephale. 2001;28(3):266-72. [cited 05.01.2020]. Available at: https://europepmc.org/article/med/12091789.

56. Osterberg L., Blaschke T. Adherence to medication. N. Engl. J. Med. 2005;353(5):487-97

https://doi.org/10.1056/nejm200511033531819

57. Rodgers P. T., Ruffin D. M. Medication nonadherence: Part II--A pilot study in patients with congestive heart failure. Manag. Care Interface. 1998;11(9):67-9. [cited 05.01.2020]. Available at: https://europepmc.org/article/ $\mathrm{med} / 10187590$.

58. Schiff G. D., Fung S., Speroff T., McNutt R. A. Decompensated heart failure: symptoms, patterns of onset, and contributing factors. Am. J. Med. 2003;114(8):625630. https://doi.org/10.1016/S0002-9343(03)00132-3

59. Senst B. L., Achusim L. E., Genest R. P., Cosentino L. A., Ford C. C. [et al.] Practical approach to determining costs and frequency of adverse drug events in a health care network. Am. J. Health Syst. Pharm. 2001;58(12):1126-32. https://doi.org/10.1093/ajhp/58.12.1126

60. Nikolaev N. A . Skirdenko Yu. P. Assessment of individual risk of food interactions against the background of warfarin. Terapevticheskiy arkhiv. 2021;2;187-192. https://doi.org/10.26442/00403660.2021.02.200611

61. Stevens V. J., Obarzanek E., Cook N. R., Lee I. M., Appel L. J. [et al.] Trials for the Hypertension Prevention Research G. Long-term weight loss and changes in blood pressure: results of the Trials of Hypertension Prevention, phase II. Ann. Intern. Med. 2001;134:1-11. [cited 05.01.2020]. Available at: http://citeseerx.ist.psu. edu/viewdoc/download?doi=10.1.1.868.1085\&rep=rep1\&t ype $=$ pdf

62. Whelton P. K., Appel L. J., Espeland M. A., Applegate W. B., Ettinger W. H. [et al.] Sodium reduction and weight loss in the treatment of hypertension in older persons: a randomized controlled trial of nonpharmacologic interventions in the elderly (TONE). TONE Collaborative Research Group. JAMA. 1998;279:839-846. https://doi.org/10.1001/jama.279.11.839

63. Puchin'yan N. F., Dovgalevskiy Ya. P., Dolotovskaya P. V., Furman N. V. The adherence to recommended therapy in patients after acute coronary syndrome, and risk of cardiovascular complications within a year after hospital admission. Rational Pharmacother. Card. 2011;7(5):567573. https://doi.org/10.20996/1819-6446-2011-7-5-57-61

64. Claxton A. J., Cramer J., Pierce C. A systematic review of the associations between dose regimens and medication compliance. Clin. Ther. 2001;23(8):1296-310. https://doi.org/10.1016/S0149-2918(01)80109-0

65. Waeber B., Leonetti G., Kolloch R., Mclnnes G. T Compliance with aspirin or placebo in the Hypertension Optimal Treatment (HOT) study. J. Hypertens. 1999;17(7):10411045. [cited 05.01.2020]. Available at: https://journals. Iww.com/jhypertension/Abstract/1999/17070/Compliance with_aspirin_or_placebo_in the.22.aspx.

66. Mazzaglia G., Ambrosioni E., Alacqua M., Filippi A., Sessa $\mathrm{E}$. [et al.] Adherence to antihypertensive medications and cardiovascular morbidity among newly diagnosed hypertensive patients. Circulation. 2009;120(16):1598-605. https://doi.org/10.1161/CIRCULATIONAHA.108.830299

67. Naderi S. H., Bestwick J. P., Wald D. S. Adherence to drugs that prevent cardiovascular disease: meta-analysis on 376,162 patients. Am. J. Med. 2012;125:882-887. https://doi.org/10.1016/j.amjmed.2011.12.013

68. Benson J., Britten N. Patients' views about taking antihypertensive drugs: questionnaire study. BMJ. 2003;326(7402):1314-1315.

https://doi.org/10.1136/bmj.326.7402.1314

69. Gupta P., Patel P., Strauch B., Lai F. Y., Akbarov A. [et al.] Biochemical screening for nonadherence is associated with blood pressure reduction and improvement in adherence. Hypertension. 2017;70:1042-1048. https://doi.org/10.1161/HYPERTENSIONAHA.117.09631

70. Jung O., Gechter J. L., Wunder C., Paulke A., Bartel C. [et al.] Resistant hypertension? Assessment of adherence by toxicological urine analysis. J. Hypertens. 2013;31:766774. https://doi.org/10.1097/HJH.0b013e32835e2286
71. Tomaszewski M., White C., Patel P., Masca N., Damani R. [et al.] High rates of non-adherence to antihypertensive treatment revealed by high-performance liquid chromatographytandem mass spectrometry (HP LC-MS/MS) urine analysis. Heart. 2014;100:855-861.

https://doi.org/10.1136/heartjnl-2013-305063

72. Hohlov A. L., Lisenkova L. A., Rakov A. A. Analiz faktorov, opredelyayushchih priverzhennost' $k$ antigipertenzivnoj terapii. Kachestvennaya klinicheskaya praktika. 2003;(4):59-66. [cited 05.01.2020]. Available at: https://www.clinvest.ru/jour/article/view/301

73. Fedorin M. M., Gorbenko A. V., Andreev K. A., Okhotnikova P. I., Demko I. V. [et al.] Medical background and potential adherence to treatment - solid cross-sectional surprises. The Russian Journal of Preventive Medicine. 2020; 23(6):15-21.

https://doi.org/10.17116/profmed20202306115

74. Birtwhistle R. V., Godwin M. S., Delva M. D., Casson R. I. [et al.] Randomised equivalence trial comparing three month and six month follow up of patients with hypertension by family practitioners. BMJ. 2004;328(7433):204. https://doi.org/10.1136/bmj.37967.374063.EE

75. Pharmaceutical Group of the European Union (PGEU) «Targeting Adherence», May 2008. [cited 05.01.2020]. Available at: https://www.pgeu.eu/en/policy/5-adherence.html

76. Fesenko E. V., Konovalov Ya. S., Aksenov D. V Perelygin K. V. Sovremennye problemy obespecheniya priverzhennosti pacientov pozhilogo vozrasta s serdechnososudistoj patologiej k farmakoterapii. Nauchnye vedomosti Belgorodskogo gosudarstvennogo universiteta. Seriya Medicina. Farmaciya. 2011;22(16/1):95-99. [cited 05.01.2020]. Available at: https://elibrary.ru/download/ elibrary 17439814 84905831.pdf.

77. Coleman C. I., Limone B., Sobieraj D. M., Lee S., Lee S. [et al.] Dosing frequency and medication adherence in chronic disease. J. Manag. Care Pharm. 2012;18(7):52739. https://doi.org/10.18553/jmcp.2012.18.7.527

78. Schedlbauer A., Davies P., Fahey T. Interventions to improve adherence to lipid lowering medication. Cochrane database Syst. Rev. 2010;3:CD004371.

https://doi.org/10.1002/14651858.CD004371.pub2

79. Alekseyeva T. S., Ogarkov M. Yu., Skripchenko A. E., Yankin M. Yu. Factors influencing compliance with lifestyle modification in an organized population. Systemic Hypertension. 2013;10(2):19-22. [cited 05.01.2020]. Available at: https://con-med.ru/magazines/hypertension/hypertension-02-2013/faktory vliyayushchie na priverzhennost $\mathrm{k}$ modifikatsii obraza zhizni_v_organizovannoy_populyatsii/.

80. Nikolaev N. A., Martynov A. I., Drapkina O. M., Livzan M. A., Moiseev S. V. [et al.] The First Russian consensus on the quantitative assessment of the adherence to treatment. Therapy. 2018;5:11-32 https://doi.org/10.18565/therapy.2018.5.11-32

81. Nikolaev N. A., Skirdenko Y. P., Bunova S. S., Ershov A. V. Rational Pharmacotherapy in Cardiology: from Routine Control to Effective Management. Rational Pharmacotherapy in Cardiology. 2017;13(5):609-614. https://doi.org/10.20996/1819-6446-2017-13-5-609-614

82. Pogosova G. V. Compliance to treatment of arterial hypertension and ischemic heart disease - Key condition of lowering of cardiovascular mortality. Kardiologiia. 2007:3:79-84. [cited 05.01.2020]. Available at: https:// www.researchgate.net/profile/Nana-Goar_Pogosova/ publication/6335831_Compliance_to_treatment_of_ arterial hypertension and ischemic heart disease Key_condition_of_lowering_of_cardiovascular_mortality/ links $/ 5770 \mathrm{~d} 3 \overline{\mathrm{d}} 0 \overline{0} 8 \mathrm{ae} 621 \overline{9474} 882 \mathrm{ca} / \mathrm{Comp} \overline{\text { Iiance-to- }}$ treatment-of-arterial-hypertension-and-ischemic-heartdisease-Key-condition-of-lowering-of-cardiovascularmortality.pdf.

83. Jokisalo E., Enlund H., Halonen P., Takala J. Factors related to poor control of blood pressure with antihypertensive drug therapy. Blood Press. 2003;12(1):49-55. [cited 05.01.2020]. Available at: https://europepmc.org/article/ $\mathrm{med} / 12699136$.

84. Strokova E. V., Naumova E. A., Schwartz Yu. G. Influence of an internal picture of illness, coping-strategies and the self-relation of the patients after myocardial infarction on adherence to long treatment of coronary artery disease and its regularity. Modern Studies of Social Issues. 2012;1:1169-1190. [cited 05.01.2020]. Available at: 
file://C:/Users/Usere/Downloads/vliyanie-vnutrenneykartin-bolezni-koping-strategiy-i-samootnosheniyapatsientok-perenesshih-infarkt-miokarda-na-regulyarnosti-priverjennost-k-dlitelnoy-terapii-ishemicheskoy-bolezniserdtsa.pdf.

85. Strokova E. V., Naumova E. A., Shvarts Y. G. Dynamics of affective disorders during long-term atorvastatin taking, patients relation to illness and adherence to statin therapy of patients with high risk of manifestation of coronary artery disease. Sovremennye problemy nauki i obrazovaniya 2011;6:18. [cited 05.01.2020]. Available at: https://science-education.ru/pdf/2011/6/69.pdf.

86. Tarasenko E. V., Naumova E. A., Shvarc Yu. G. Priverzhennost' k dlitel'nomu lecheniyu i faktory na nee vliyayushchie. Fundamental'nye issledovaniya. 2007;9:5758. [cited 05.01.2020]. Available at: https://elibrary.ru/ download/elibrary_12956141_66110970.pdf.

87. Conn V. S., Ruppar T. M., Chase J. A., Enriquez M., Cooper P. S. Interventions to improve medication adherence in hypertensive patients: systematic review and meta-analysis. Curr. Hypertens. Rep. 2015;17:94. [cited 05.01.2020]. Available at: https://link.springer.com/ article/10.1007/s11906-015-0606-5.

88. Parati G., Omboni S. Role of home blood pressure telemonitoring in hypertension management: an update. Blood Press Monit. 2010;15:285-295. https://doi.org/10.1097/MBP.0b013e328340c5e4

89. Fletcher B. R., Hartmann-Boyce J., Hinton L., McManus $R$. J. The effect of selfmonitoring of blood pressure on medication adherence and lifestyle factors: a systematic review and meta-analysis. Am. J. Hypertens. 2015;28:1209-1221. https://doi.org/10.1093/ajh/hpv008

90. Konradi A. O., Polunicheva E. V. Nedostatochnaya priverzhennost' $k$ lecheniyu arterial'noj gipertenzii: prichiny i puti korrekcii. Arterial'naya gipertenziya. 2004;10(3):137143.

91. Burnier M., Brede Y., Lowy A. Impact of prolonged antihypertensive duration of action on predicted clinical outcomes in imperfectly adherent patients: comparison of aliskiren, irbesartan and ramipril. Int. J. Clin. Pract. 2011;65:127-133.

https://doi.org/10.1111/j.1742-1241.2010.02616.x

92. Lowy A., Munk V. C., Ong S. H., Burnier M., Vrijens B. [et al.] Effects on blood pressure and cardiovascular risk of variations in patients' adherence to prescribed antihypertensive drugs: role of duration of drug action. Int. J. Clin. Pract. 2011:65:41-53.

https://doi.org/10.1111/j.1742-1241.2010.02569.x

93. Nikolaev N. A., Martynov A. I., Bojcov S. A., Drapkina O. M., Sychev D. A [et al.] The first Russian consensus on quantitative assessment of treatment outcome. Medical News of North Caucasus. 2018;1.2(13):259-271. https://doi.org/10.14300/mnnc.2019.14072

94. Marcevich S. Yu., Kutishenko N. P., Tolpygina S. N., Lukina Yu. V. [et al.] Effektivnost' i bezopasnost' lekarstvennoj terapii pri pervichnoj i vtorichnoj profilaktike serdechnososudistyh zabolevanij. Rekomendacii VNOK, 2011. Rational Pharmacotherapy in Cardiology. 2011;7(5):2-72. https://doi.org/10.20996/1819-6446-2011-7-5

95. Martsevich S Yu, Kutishenko N. P Lukina Yu. V Tolpygina S. N., Ivanova L. P. [et al.] Self-monitoring and treatment of chronic non-communicable diseases in the context of the COVID-19 pandemic. Consensus of experts of the National society of evidence-based pharmacotherapy and the Russian society of the prevention of non-communicable diseases. Cardiovascular Therapy and Prevention. 2020;19(3):2567.

https://doi.org/10.15829/1728-8800-2020-2567

96. Skirdenko Y. P., Shustov A. V., Zherebilov V. V., Nikolayev N. A. Treatment Adherence as a New Choice Factor for Optimization of Oral Anticoagulation Therapy in Patients with Atrial Fibrillation and Hemostatic Gene Polymorphisms. Rational Pharmacotherapy in Cardiology. 2016;12(5):494-502.

https://doi.org/10.20996/1819-6446-2016-12-5-494-502

97. Bunova S. S., Zhernakova N. I., Skirdenko Yu. P., Nikolaev N. A. Adherence to therapy, lifestyle modification and medical support of cardiovascular patients. Cardiovascular Therapy and Prevention. 2020;19(6):2665. https://doi.org/10.15829/1728-8800-2020-2665

98. Nikolaev N. A., Martynov A. I., Skirdenko lu. P., Ageev F. T., Andreev K. A. [et al.] Management of treatment on the basis of adherence. Consensus document - Clinical recommendations. RSMSIM, SSGR, NATH, SEBN, GS RAS, RSH, RSP. Consilium Medicum. 2020;22(5):9-18. https://doi.org/10.26442/20751753.2020.5.200078

99. Skirdenko Y. P., Nikolaev N. A. Algorithm for the Choice of Anticoagulant for Patients with Atrial Fibrillation. Rational Pharmacotherapy in Cardiology. 2020;16(2):199-205. https://doi.org/10.20996/1819-6446-2020-04-16 